\title{
STRUKTURY, HISTORIA I PRAXIS. O SPORZE SARTRE'A Z LEVI-STRAUSSEM Z DZISIEJSZEJ PERSPEKTYWY
}

\author{
MAŁGORZATA KOWALSKA
}

\begin{abstract}
Abstrakt: W artykule zostaje przypomniany historyczny spór między Sartrem i LéviStraussem dotyczący rozumienia dialektyki (relacji między rozumem dialektycznym i rozumem analitycznym), który był zarazem sporem o pojęcia historii i struktury, status świadomej podmiotowości i rolę swobodnego działania, „sporem o człowieka” i sposób uprawiania antropologii, w tym o stosunek filozofii do nauki/nauk empirycznych. Zamiast prostego przeciwstawienia stanowisk Sartre’a i Lévi-Straussa autorka stara się wydobyć dość złożoną, dialektyczną grę między nimi, podkreślając jednak ich ostateczną opozycyjność, którą wiąże z nieusuwalnym napięciem między biegunami całej nowoczesnej filozofii i kultury, przede wszystkim biegunami subiektywizmu i obiektywizmu. To napięcie ujawnia się w różnych sposobach pojmowania i badania człowieka w ogóle (jako przede wszystkim podmiotu i projektu lub, przeciwnie, przedmiotu i uwarunkowanego elementu znacznie szerszego uniwersum), ale także w relacji między kulturą i naturą oraz - wreszcie - relacji między różnymi kulturami.

Celem artykułu jest nie tylko rekonstrukcja historycznego sporu, ale również jego aktualizacja, tj. odniesienie go do całkowicie współczesnych dyskusji o charakterze teoretycznym
\end{abstract}


i praktycznym, moralno-politycznym, dotyczących takich zagadnień jak status umysłu i świadomości, a także kwestii ekologicznych i pytań o możliwe i pożądane relacje między światem zachodu oraz innymi kulturami. W świetle artykułu napięcie między stanowiskami à la Sartre i à la Lévi-Strauss jawi się we współczesnych dyskusjach jako obecne i żywe.

Słowa kluczowe: antropologia, dialektyka, fenomenologia, historia, podmiot, praxis, struktura, strukturalizm, wolność 


\section{Stawka sporu}

Polemika Sartre’a z Lévi-Straussem, która miała miejsce na początku lat sześćdziesiątych dwudziestego wieku, na pewnym poziomie ma już znaczenie tylko historyczne. Obaj autorzy należą do klasyki myśli współczesnej, ale próżno dziś szukać ich wyznawców czy wiernych kontynuatorów. Chociaż zarówno fenomenologia, jak strukturalizm wciąż są żywe w tym sensie, że inspirują współczesne myślenie, ulegając rozmaitym przekształceniom, to spór między nimi zdecydowanie stracił na ostrości. Już francuscy „poststrukturaliści” - Derrida, Deleuze, Foucault, Lyotard - w pewien sposób zatarli ten spór, a nawet intencjonalnie unieważnili, problematyzując i kwestionując założenia obu „szkół”, oddalając jednocześnie fenomenologiczne pojęcie podmiotu i inwariantne struktury. Skądinąd w retrospektywnych podręcznikowych ujęciach przedmiot kontrowersji został skrajnie uproszczony, sprowadzony do sporu o istnienie lub śmierć „człowieka”. Z tej perspektywy Sartre jawi się jako ostatni obrońca nowożytnego humanizmu („,ostatni wielki filozof dziewiętnastego wieku”, jak ujął to Foucault), a Lévi-Strauss jako bezkompromisowy rzecznik nowej obiektywnej nauki i nowej posthumanistycznej epoki. Postaram się pokazać, że chociaż takie uproszczenie nie jest bezpodstawne, to wiąże się ono z pominięciem dość skomplikowanej gry między dwoma stanowiskami - jednocześnie odnotuję to, co w tej grze i w tym sporze pozostaje aktualne.

Zakreślmy wstępnie przedmiot i stawkę sporu. Chodzi przy tym zarówno o spór jawny, wprost wyartykułowany w niektórych tekstach i wypowiedziach obu autorów, jak i o to, co można uznać za jego ogólniejszą filozoficzną bazę czy ogólniejszy filozoficzny kontekst, które dają się zrekonstruować na podstawie całokształtu ich twórczości. Jawna polemika Sartre’a z Lévi-Straussem i Lévi-Straussa z Sartrem zajmuje w ich twórczości niewiele miejsca: parędziesiąt stron w Critique de la raison dialectique Sartre'a, jeden rozdział w Myśli nieoswojonej Lévi-Straussa plus trochę wypowiedzi jednego i drugiego rozsianych w opublikowanych rozmowach lub tylko nagranych wywiadach (Sartre 1960, 487-505; LéviStrauss $2001 \mathrm{a}^{1}$; Pingaud i Sartre 1966) ${ }^{2}$. Ale oczywiste jest to, że za wypowiedziami wprost

\footnotetext{
1 Rozdział Dialektyka i historia.

2 Istotne są w tym kontekście wypowiedzi ustne obu autorów przytaczane w nagraniu radiowym France Culture z 1 października 2014 roku, dostępne na stronie www.franceculture/emissions/les-nouveaux-cheminsde-la-connaissance/duels-de-philosophes-34-sartre-vs-levi-strauss.
} 
polemicznymi kryje się wiele założeń i tez wypowiedzianych w innych miejscach i przy innych okazjach.

Polemika ma charakter zarówno metodologiczny, jak ontologiczny, a na pewnym poziomie także moralno-polityczny. Obu autorom chodzi o stworzenie antropologii, o „zrozumienie, czym jest człowiek”. Ale w jaki sposób myśleć o człowieku i go poznawać, jak w konsekwencji określać jego „naturę” i jakie mu przypisywać miejsce w bycie, jakie wreszcie wyciagać z tego wnioski moralne i polityczne - to, najogólniej rzecz ujmując, stanowi stawkę sporu. $\mathrm{Na}$ nieco mniej ogólnym poziomie kontrowersja dotyczy modelu racjonalności, znaczenia historii i roli, jaką odgrywa w niej świadome działanie, możliwej jedności historii i samej ludzkości, a także, choć niebezpośrednio, statusu i genezy sensu. Przyjrzyjmy się tym problemom mniej więcej po kolei (ściśle odróżnić ich się nie da), podążając częściowo za litera jawnej polemiki, ale rekonstruując również stojące za nią ogólniejsze przesłanki, bardziej skomplikowane i niejednoznaczne, niż zwykło się sądzić.

\section{Rozum dialektyczny i analityczny, czyli pytanie o możliwość filozofii}

W rozdziale Myśli nieoswojonej zawierającym bezpośrednie odniesienie do Sartre’a jako autora Krytyki dialektycznego rozumu sporo miejsca zajmuje obecne już w tytule owego rozdziału pojęcie dialektyki. Wbrew późniejszym stereotypom (do upowszechnienia których przyczyniła się bardzo skądinąd interesująca synteza czterdziestu pięciu lat filozofii francuskiej autorstwa Vincenta Descombes'a; zob. Descombes 1997) strukturalizm w swojej najbardziej bojowej i „klasycznej” fazie bynajmniej tego pojęcia nie odrzucał, pojawia się ono w pozytywnym znaczeniu zarówno w tekstach Lévi-Straussa, jak Althussera, choć podlega dość daleko idącej, by nie rzec swobodnej reinterpretacji. Powód wydaje się oczywisty: istotną, jeśli nie podstawową inspiracją dla najważniejszych rzeczników strukturalizmu a w tym czasie także dla Sartre’a - pozostawał marksizm, z którego dialektyki wyrugować łatwo się nie da. Pozostawało zatem odróżnić „dobrą” dialektykę Marksa od „złej” dialektyki Hegla, utożsamiając tę ostatnią z metafizyką czy ideologia, a tę pierwszą zbliżając tak dalece, jak to możliwe, do zasad racjonalności naukowej pojmowanej na sposób strukturalistyczny. Takiego reinterpretacyjnego zabiegu dokonali Lévi-Strauss i Althusser (Althusser 2009; Althusser 1972). Z tej perspektywy rozumienie dialektyki przez Sartre’a jawi się jeszcze, 
choćby wbrew jego intencjom, jako beznadziejnie heglowskie albo po prostu subiektywistyczno-idealistyczne.

Zacznijmy od krótkiego przypomnienia, jak dialektykę i rozum dialektyczny w swoim marksizującym okresie pojmował Sartre. Obszerne rozważania na ten temat znajdujemy w pierwszych rozdziałach Critique de la raison dialectique, a po części już w poprzedzających tę pracę, napisanych nieco wcześniej Questions de méthode. W świetle tych rozważań nie ulega wattpliwości, że ambicją Sartre’a i tym, co uważał on za właściwe zadanie dialektyki, było przekroczenie klasycznej opozycji między idealizmem i materializmem czy naturalizmem, zaproponowanie „dialektyki krytycznej”, która w odróżnieniu od dogmatycznej - za jaka filozof uznawał zarówno Heglowską dialektykę ducha, jak i Engelsowską dialektykę przyrody - byłaby zdolna opisać całokształt ludzkiego doświadczenia jako zarazem subiektywnego i obiektywnego, jednostkowego i zbiorowego, mającego podstawę materialną, ale też wymiar świadomościowy, uwikłanego w cały zastany świat i cała jego historię, a zarazem mającego charakter projektu i mogącego ten świat przekształcać. Słowem: chodziło o dialektykę, która mogłaby ujać złożone doświadczenie jednostkowe i zbiorowe działanie w świecie. Dialektyka ma tu status metody, ale chodzi o metodę pozwalająca ujać ruch samej rzeczywistości, faktyczne relacje między działająca jednostką i innymi jednostkami oraz między nimi wszystkimi a materia jako ich ontologiczną podstawą i stałym otoczeniem. W grę wchodziły dialektyka i rozum dialektyczny definiowane zarazem metodologicznie i ontologicznie. „Dialektyka jako pewien typ racjonalności - pisze Sartre - winna odsłonić się w bezpośrednim i codziennym doświadczeniu jednocześnie jako obiektywny związek faktów i jako metoda poznawania oraz określania tego związku" (Sartre 1960, 130). Filozof przyznaje wprawdzie, iż założenie, że relacje między ludzkim działaniem i bytem tout court mają charakter dialektyczny, jest tylko hipoteza, ale za cel stawia sobie sprawdzenie tej hipotezy w sposób w pewnym sensie eksperymentalny, mianowicie przez jej zastosowanie do wyjaśnienia własnych doświadczeń refleksyjnego podmiotu w jego relacjach z innymi ludźmi i z oporem materii w kontekście dotychczasowej historii. Sprawdzian, zwany „doświadczeniem krytycznym”, ma więc charakter fenomenologiczno-hermeneutyczny: chodzi o analizę własnych przeżyć, ale też o poszukiwanie dla nich coraz bardziej rozległego kontekstu i ich warunków możliwości, zawsze już zastanych, materialnie i historycznie ukształtowanych.

Z tej perspektywy rozum niedialektyczny, a jedynie analityczny, pozwalający wyodrębniać poszczególne składniki czy warstwy syntetycznego doświadczenia, jest rozumem 
zaledwie pomocniczym i cząstkowym. Sartre bynajmniej go nie lekceważy i z niego nie rezygnuje, programowo nawet czyni z analizy moment swojej regresywno-progresywnej metody, nazywanej też metodą analityczno-syntetyczną (Sartre 1960, 97). To, co rozumie przez regresję, polega, niemal w duchu kartezjańskim, na rozkładaniu skomplikowanego węzła doświadczenia na prostsze i abstrakcyjne momenty: jednostkowy „organizm praktyczny", serie niezależnych od siebie, ale mimowolnie ze soba powiązanych praktyk jednostkowych, działanie grupowe na etapie formowania się pewnego „my”, funkcjonowanie grupy zinstytucjonalizowanej, konflikty między grupami itd. Odnotowując, że sam Sartre posługuje się metodami analitycznymi, łącznie z dokonywaniem klasyfikacji (Lévi-Strauss 2001a, 326), Lévi-Strauss ma więc oczywiście rację, ale nie jest to racja wbrew Sartre'owi i jego metodologicznej samowiedzy. Kością niezgodny pozostaje natomiast pojmowanie relacji między rozumem analitycznym i dialektycznym. Dla Sartre'a analiza jest w założeniu wstępem do myślenia dialektycznego, tożsamego z myśleniem syntetycznym i ,progresywnym”, które wszystkie wyodrębnione momenty wprawi w ruch i dynamicznie ze sobą powiąże, pokazując grę jedności i opozycji między nimi i wpisując je w globalny ruch historii, nigdy przy tym nie tracąc z oczu jednostkowego „doświadczenia krytycznego”. Przejście od analizy do dialektyki jest tu jakościowa zmiana poziomu refleksji. A raczej sama analiza ma tu wartość o tyle, o ile jest od początku podporządkowana perspektywie dialektycznej i wyodrębnia swoje momenty zgodnie z potrzebami poszukiwanej syntezy. Rozum analityczny staje się uzurpatorski w swoich roszczeniach poznawczych i zgoła fałszywy, gdy zapomina o własnych ograniczeniach, o swojej abstrakcji, gdy elementy analizy, w szczególności te dotyczące aktualnych praktyk zbiorowych, bierze za samą rzeczywistość i gdy tę rzeczywistość unieruchamia, wyrywa z historycznego stawania się. A także, jeśli nie przede wszystkim, kiedy siląc się na czysty obiektywizm, wszelkie historyczne i subiektywnie kształtowane fakty stara się ujmować tylko z zewnątrz, nie wiążąc ich z jednostkowymi lub zbiorowymi przeżyciami i projektami. Słowem, gdy ludzi bada tak samo jak mrówki, do przeżyć których nie ma żadnego dostępu i co do których można zakładać, że nie mają projektów i same przez się nie tworzą sensu (Sartre 1960, 124)3. Rozum analityczny to w sumie tyle co rozum pozytywistycznie naukowy, wyjaśniający, w każdym razie próbujący wyjaśniać, ale nierozumiejący. Nie negując wartości dostarczanego przezeń poznania, Sartre bardzo mocno stoi więc na stanowisku, że jest to poznanie niewystarczające i że myślenie

3 Porównanie cytowane przez Lévi-Straussa (2001, 327). 
filozoficzne, tożsame z dialektycznym, powinno je przekroczyć. Lévi-Strauss słusznie zauważa, że stosunek Sartre’a do rozumu analitycznego jest dwoisty: raz uznaje on go za podrzędny, innym razem zdecydowanie go krytykuje (Lévi-Strauss 2001a, 327), ale nie ma tu żadnej logicznej sprzeczności. Z perspektywy autora Critique rozum analityczny powinien po prostu znać swoje miejsce. Albo, co na jedno wychodzi, nauki pozytywne i formalne nie moga zastapić filozofii.

Intencja dialektycznego przedsięwzięcia à la Sartre jest jasna: chodzi o przekroczenie opozycji i pokazanie dynamicznych relacji między świadomością i materią, jednostką i zbiorowościa, różnymi zbiorowościami itd., w ramach obejmującej wszystko historii. Pytanie brzmi, na ile udaje mu się rzeczywiście sprostać temu zadaniu. W jego koncepcji dialektyki, w jej zastosowaniu do szczegółowych analiz, ale po prawdzie już w samych jej założeniach uderzaja przynajmniej dwie rzeczy: po pierwsze to, że mimo deklarowanego wychodzenia poza dialektykę „dogmatyczna” autor Critique przejmuje znaczną część klasycznej Heglowskiej terminologii z pojęciami „negacji”, „sprzeczności”, „obiektywizacji”, „alienacji”, „znoszenia” i „mediacji” na czele. W zestawieniu z jego wcześniejszą koncepcją, wyłożoną w Bycie i nicości, gdzie relacje między bytem-dla-siebie i bytem-w-sobie oraz między bytem-wsobie i bytem-dla-innego miały charakter fundamentalnego ontologicznego konfliktu, obecna tu zmiana polega przede wszystkim na przypisaniu zasadniczej roli mediacji: działanie zapośrednicza projekt z materią, aktualne i przeszłe działania innych zapośredniczaja działania jednostek, sama materia zapośrednicza wszelkie międzyludzkie relacje itd. Ale w ten sposób Sartre raczej zbliża się do Hegla niż od niego oddala, nawet jeśli jego założenia są materialistyczne w tym sensie, że uznaja ontologiczny prymat materii nad „duchem”. Cowięcej, postulat „doświadczenia krytycznego”, wyraźnie związany z tradycją fenomenologiczna, nieuchronnie premiuje subiektywny punkt wyjścia wszelkich dociekań. Nie jest zatem przypadkiem, że ostatecznie za źródło dialektycznego rozumu Sartre uznaje jednostkowe działanie, jednostkowe przekraczane świata i borykanie się z jego oporem, jednostkowe „negacje” i „negacje negacji”, jednostkowy „totalizujący projekt” (totalizujący, to znaczy organizujący świat wokół „ja” i w ten sposób czyniący z niego pewną subiektywną całość, chociaż jest to całość zawsze otwarta, „totalność zdetotalizowana”) - podnosząc to działanie jako podstawę wszelkiej praxis do rangi „dialektyki konstytuującej”. Działaniu zbiorowemu, w ramach którego „ja” przekształca się w „my”, przyznany zostaje status jedynie „dialektyki konstytuowanej”, tj. ontologicznie wtórnej, a nieintencjonalne i sprzeczne 
z intencjami „organizmów praktycznych” oddziaływanie materii na rezultaty działań ochrzczone zostanie mianem antydialektyki (która pozostaje wszak w ogólniejszych dialektycznych związkach - w ramach „dialektyki ogarniającej” - z dwiema poprzednimi). W sumie wiele wskazuje na to, że jeśli Sartre przekroczył idealizm Hegla, to raczej w stronę idealizmu bardziej subiektywnego (typu Fichteańskiego), w osobliwy sposób powiązanego z materializmem brutalnym - by nie rzec wulgarnym - w tym sensie, że operujaccym ubogim pojęciem materii, generalnie sprowadzanej do biernego podłoża i nieznośnie bezwładnego oporu wobec jednostkowych i zbiorowych projektów.

Lévi-Strauss w swojej publicznej polemice z Sartrem nie odnosi się do jego deklarowanych intencji, lecz do ich efektów. I ocenia je surowo. (A warto wspomnieć, że egzegezie Sartre’owskiej Critique Lévi-Strauss poświęcił sporo czasu, przeznaczając na ten cel specjalne seminarium w roku 1961, co świadczy chyba o szczególnej estymie, jaką darzył starszego kolege, a przynajmniej o uznawaniu jego istotnej roli w kształtowaniu współczesnego myślenia.) W odróżnieniu od Althussera nie poddaje wprawdzie bezpośredniej krytyce Heglowskich kategorii, nie kwestionuje wprost pojęć negacji czy alienacji (może dlatego, że są mu tak obce, iż niemal dla niego niezrozumiałe, a może dlatego, że uważa je za podrzędne i jako takie niewarte specjalnej uwagi), ale bardzo wyraźnie atakuje w myśleniu Sartre’a dwie rzeczy: subiektywizm i historyzm, a ściślej: czynienie z historii mitu. Do tej ostatniej kwestii przejdę później, tymczasem skupmy się na pierwszej. Z perspektywy Lévi-Straussa Sartre pozostaje w gruncie rzeczy kartezjanistą przywiązanym nie do kartezjańskiej metody, lecz do cogito, w najlepszym razie zastępującym „ja” przez „my”, usiłującym przekształcić myślenie jednostkowe w grupowe, solipsyzm jednostki w solipsyzm grupy (Lévi-Strauss 2001a, 331)4 . Lévi-Strauss kwestionuje zatem węzłowy punkt Sartre’owskiej dialektyki, jakim jest czy powinno być jej zakorzenienie w fenomenologicznym doświadczeniu. Zgodnie z podstawowymi założeniami strukturalizmu, pokrewnego w tym punkcie psychoanalizie, przyjmuje, że to, czego podmiot jednostkowy lub zbiorowy może być świadomy, nie pokrywa się nigdy z obiektywnymi uwarunkowaniami i obiektywnym sensem jego działań, które można rozpoznać tylko z zewnątrz (Lévi-Strauss 2001a, 337) ${ }^{5}$. Autor Myśli

4 „Sartre stał się faktycznie więźniem swojego cogito. U Kartezjusza pozwalało ono dojść do tego, co uniwersalne, atoli pod warunkiem, że pozostanie się na płaszczyźnie psychologicznej i indywidualnej. Socjologizując cogito, Sartre zamienia tylko jedno więzienie na drugie. Odtąd grupa i epoka każdego podmiotu zastępują świadomość bezczasową".

5 „Wydaje nam się, że pod tym względem Sartre zachował nie więcej niż połowę z połączonej lekcji Marksa i Freuda, ci ostatni nauczyli nas bowiem, że człowiek posiada sens tylko wtedy, gdy spogląda na siebie 
nieoswojonej idzie nawet dalej, zakładając, że obiektywne uwarunkowania ludzkiego myślenia i ludzkich działań są ostatecznie tożsame z prawami rządzącymi materią na jej poziomach

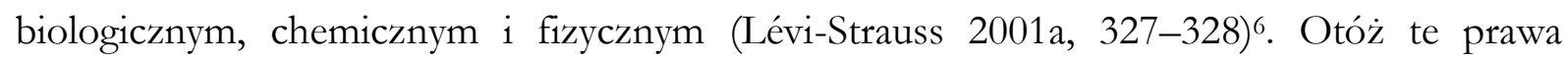
rozpoznaje rozum naukowy, czyli ,zewnętrzny” i analityczny, badający fakty i strukturalne związki między nimi.

Czym może być w tym kontekście rozum dialektyczny? Oczywiście nie żadnym przeciwieństwem ani przezwyciężeniem rozumu analitycznego, żadną nową jakością którą mogłaby do rozważania człowieka i do rzeczywistości w ogóle wnieść filozofia w odróżnieniu od nauki (zbioru pozytywnych nauk), ale tylko i aż stałym wysiłkiem rozumu analitycznego, prowadzącym do wychodzenia poza jego dotychczasowe granice, do ustalania związków między tym, co w dotychczasowej wiedzy o świecie niepowiązane, do ogarniania i rozjaśniania coraz większych poziomów złożoności. Jednocześnie jednak - bo to dla LéviStraussa dwie strony tej samej metody - wysiłkiem prowadzącym do rozkładania samej złożoności na elementy pierwsze:

[...] rozum dialektyczny nie jest dla nas çymśs innym niż rozum analityczny ani czymś, co mogłoby być podstawą bezwzględnej oryginalności porządku ludzkiego; rozum dialektyczny jest csymś wiecej w łonie samego rozumu analitycznego: jest warunkiem koniecznym do tego, by ośmielił się on przystapić do rozłożenia tego, co jest ludzkie, na nieludzkie [...] (Lévi-Strauss 2001a, 327).

Ujmując to w syntetycznym skrócie, rozum dialektyczny jest „rozumem analitycznym w działaniu". Wbrew insynuacjom Sartre’a rozum analityczny nie tylko nie jest rozumem „leniwym”, poprzestającym na rejestrowaniu zewnętrznych faktów albo wyróżnianiu abstrakcyjnych i statycznych momentów, ale właśnie odważnie wykracza zarówno poza

w perspektywie usensowniającej; aż dotąd zgadzamy się z Sartre’em, trzeba jednak tu dodać, że sens ów nigdy nie jest tym właściwym: superstruktury to akty chybione, którym społecznie »udało się«. Próżno więc byłoby oczekiwać najprawdziwszego usensownienia ze strony świadomości historycznej”.

6 „[...] wierzymy, iż ostatecznym celem nauk humanistycznych nie jest konstytuowanie człowieka, lecz rozczłonkowanie w celu rozwiązania jego zagadki. Wielkie znaczenie etnologii polega na tym, że stanowi pierwszy etap procedury, na którą składa się więcej stopni - ponad progiem empirycznej różnorodności ludzkich społeczeństw; analiza etnograficzna pragnie dotrzeć do inwariantów, które - jak wynika z tej pracy sytuują się czasem w najbardziej nieoczekiwanych punktach. [...] Nie wystarcza jednak włączenie poszczególnych grup ludzkich w ludzkość powszechną - ten pierwszy krok jest wstępem do dalszych poczynań [...], które należą do nauk ścisłych i przyrodniczych: reintegracji kultury w naturze i wreszcie reintegracji życia w całokształcie jego warunków fizykochemicznych". 
ograniczenia dotychczasowej wiedzy naukowej, jak i poza metafizyczne dogmaty - i w tym sensie, nie zmieniając swojej metody, jest wewnętrznie dialektyczny.

$\mathrm{Na}$ tym poziomie sporu mogłoby się wydawać, że propozycja Lévi-Straussa jest zwykłą antyteza propozycji Sartre’a, i to antytezą zewnętrzną, tj. taka, która ze swoją tezą nie ma istotnego związku, bo wychodzi z radykalnie odmiennych, a zarazem niezależnych podstawowych założeń. Kiedy jednak uważniej wczytać się w polemiczny tekst Lévi-Straussa, sprawa okazuje się nie taka prosta. I nie chodzi o to, że Lévi-Strauss explicite przyznaje Sartre’owi szczegółowe czy punktowe zasługi w rozjaśnieniu konkretnych zjawisk czy relacji społecznych, co można by ostatecznie uznać za kurtuazję wobec „wielkiego filozofa”. Chodzi o związek między dwiema z pozoru alternatywnymi i zgoła wykluczającymi się propozycjami na znacznie ogólniejszym a zarazem głębszym poziomie. Poza i ponad sprzeciwem wobec subiektywizowania rozumu dialektycznego przez Sartre’a Lévi-Strauss w swojej polemice z nim wyraźnie komplikuje własne stanowisko w dwóch powiązanych ze sobą punktach. Po pierwsze, rewiduje swoją wcześniejszą koncepcję (albo tylko koryguje jej uproszczoną wykładnię), zgodnie z którą ludzie (tu konkretnie: członkowie kultur zwanych prymitywnymi) są generalnie nieświadomi reguł, wedle których działają, przyznając, że myślenie i działanie świadome maja jednak zasadniczy udział w organizowaniu społecznego świata (Lévi-Strauss 2001a, 334)7. Po drugie, jednocześnie rewiduje, a nawet odwołuje swoją niegdysiejszą tezę o zasadniczej opozycji miedzy naturą oraz kulturą, postulując ich jedność i ich łączne badanie, i problematyzuje redukcjonizm rozumiany jako sprowadzanie zjawisk złożonych do prostych. Badanie naukowe w jego rozumieniu nie może w pewien sposób nie redukować kultury do natury, ale też samą naturę musi pojmować przez prymat kultury. Za postulatem wiązania sposobów myślenia i działania z prawami (strukturami) samej materii nie kryje się tu w żadnym razie „wulgarnomaterialistyczny” pomysł sprowadzania kultury, myślenia i działania do znanych praw przyrody, lecz idea i postulat odkrycia nieznanych jeszcze praw, pozwalających ująć specyfikę świadomego myślenia i działania, które samą materię, zdolną

\footnotetext{
„Dziś musimy przyznać: mimowolnie poparliśmy te błędne interpretacje, zbyt często - w Les Structures élémnentaires de la parenté - sprawiając wrażenie, że poszukujemy nieuświadomionej genezy wymiany małżeńskiej. Należało wyraźniej przeprowadzić rozróżnienie między wymianą taką, jaka się wyraża spontanicznie i bezwzględnie w praktyce grup, a świadomymi i przemyślanymi regułami, za pomocą których te same grupy - czy też ich filozofowie - zajmują się jej kodyfikowaniem i kontrolowaniem. Jeśli można wyciagnąć jakąś naukę z badań etnograficznych ostatnich dwudziestu lat, to tę, że drugi wymieniony tu aspekt jest dużo ważniejszy, niż to na ogół podejrzewali obserwatorzy [...]”.
} 
zrodzić umysł ze wszystkimi jego konstrukcjami, kazałyby postrzegać jako rzeczywistość niebywale i może nieskończenie złożoną:

Z chwila kiedy osiagniemy zrozumienie życia jako funkcji bezwładnej materii, dane nam będzie odkryć, że materia ta posiada własności całkiem różne od tych, jakie przypisywaliśmy jej poprzednio. Nie można więc szeregować poziomów redukcji jako wyższych i niższych, należy się bowiem spodziewać, że w wyniku redukcji poziom uważany za wyższy przekaże retroaktywnie coś ze swego bogactwa poziomowi niższemu, do którego zostanie sprowadzony. Wyjaśnienie naukowe nie polega na przechodzeniu od złożoności do prostoty, lecz na zastępowaniu złożoności mniej zrozumiałej przez bardziej zrozumiała (Lévi-Strauss 2001a, 329).

Taka koncepcja materii jest oczywiście, choć tylko implicite, polemiczna wobec koncepcji Sartre'a, który także w swoim marksizującym, „materialistycznym” okresie nie jest w stanie pozbyć się myśli o zasadniczej, nieredukowalnej i ostatecznie niewyjaśnialnej różnicy między materią jako bytem-w-sobie i świadomym umysłem jako bytem-dla-siebie, ale na ogólniejszym poziomie pokrywa się z Sartre’owską, dialektyczną i mediacyjną intencją przekroczenia opozycji między naturą i kultura, materią i duchem. $\mathrm{Na}$ tym ogólnym poziomie tak dla Sartre’a, jak dla Lévi-Straussa rozum dialektyczny jest rozumem wnikającym w złożoność, szukającym pomostów i mediacji między opozycjami, „jedności przeciwieństw”.

Różnica między stanowiskami obydwu autorów pozostaje jednak istotna. Z jednej strony mamy do czynienia $\mathrm{z}$ ideą dialektyki ugruntowanej w doświadczeniu fenomenologicznym i z relatywizacją roli poznania analityczno-naukowego, z drugiej strony z pojmowaniem dialektyki jako nieustannego poszerzania i komplikowania wiedzy analityczno-naukowej oraz z relatywizowaniem wartości doświadczeń fenomenologicznych. Last but not least, spór o charakter rozumu, o związek analizy z dialektyką, jest tu również sporem o relację między filozofią i naukami pozytywnymi, o możliwość autonomii filozofii i jej ewentualny nadrzędny status wobec nauki/nauk. Lévi-Strauss, rozczarowany filozofią absolwent studiów filozoficznych, głosi nie tyle „koniec człowieka”, ile koniec filozofii w jej roszczeniach do lepszego rozumienia świata i człowieka. Dlatego antropologia filozoficzna, w której Sartre widział podstawę wszelkiej filozofii, może być dla niego już tylko antropologią kulturowa, ta zaś - częścią systemu pozytywnych nauk o materialnej rzeczywistości. Z tego punktu widzenia przeznaczeniem filozofii jest rozpuszczenie się w naukach i funkcjonowanie 
najwyżej jako ich wewnętrzny napęd, służący stałemu poszerzaniu ich pola badawczego oraz ich coraz głębszej integracji.

\section{Struktury i historia: pytanie o jedność ludzkości i genezę sensu}

Analogiczna kontrowersja, ściśle związana z poprzednią, dotyczy sposobu pojmowania relacji między strukturami i historia. Wbrew dość popularnym stereotypom ani Sartre nie przeczył istnieniu i znaczeniu struktur, ani Lévi-Strauss nie negowal znaczenia historii. W Critique termin „struktura” pojawia się bardzo często. W pewnym miejscu proponowaną przez siebie filozoficzną antropologię Sartre nazywa wręcz antropologią „historyczną i strukturalną” (Sartre 1960, 108). Ze swej strony Lévi-Strauss od stosunkowo wczesnych artykułów zebranych w tomie Antropologia strukturalna, a potem Antropologia strukturalna II uznawał, wręcz podkreślał, istotne znaczenie badań historycznych dla zrozumienia ludzkiej kultury i człowieka „w ogóle”, jednocześnie problematyzując relacje między poznaniem historycznym i antropologiczno-etnologicznym. Wedle formuly z Antropologii strukturalnej historia i etnologia/antropologia kulturowa miałyby ostatecznie stanowić Janusowe oblicza tego samego globalnego poznania, różniąc się nie przedmiotem, lecz metodą (Lévi-Strauss 2000)8. W przypadku historii jako nauki punktem wyjścia analizy są nie tyle źródła pisane, ile świadome przeżycia historycznych aktorów, podczas gdy w przypadku antropologii kulturowej czy etnologii przedmiotem zainteresowania byłyby przede wszystkim strukturalne uwarunkowania i ramy myślenia/działania, których sami aktorzy mogą być nieświadomi. Ale nawet ta metodologiczna różnica jest względna, bo badanie historyczne, o ile wykracza poza przytaczanie historycznych źródeł i wypowiedzi, co nie jest jeszcze żadną nauka, musi zmierzać do odkrywania warunków nieuświadamianych sobie przez samych aktorów. I odwrotnie: badanie etnologiczne musi wychodzić od tego, co sami aktorzy o sobie i świecie myślą oraz mówią. Względna jest również opozycja między synchronią i diachronią. Mimo postulatu poszukiwania kulturowych i historycznych inwariantów Lévi-Strauss uznaje bez oporu nie tylko istnienie „struktur diachronicznych”, pozwalających znaleźć elementy stałe w rzeczywistości zmieniającej się w czasie, ale także mnóstwo szczegółowych wariantów,

8 Rozdział Wprowadzenie: Historia i etnologia. 
zmiennych zarówno w czasie, jak i w przestrzeni, które stanowią jakby efekt swobodnej improwizacji na bazie ogólniejszej struktury, a nawet cały wachlarz odchyleń od „inwariantów” (Lévi-Strauss 2000)9. Struktura nie wyklucza zatem zmienności ani w czasie, ani w przestrzeni. Odkładając tymczasem na bok sprawę przestrzeni, powiedzmy, że Lévi-Strauss w żadnym razie nie neguje historycznego stawania się i różnicowania się struktur.

Mimo zgody na tym ogólnym poziomie (struktury nie wykluczają historii ani historia struktur) stanowiska Sartre’a i Lévi-Straussa są bardzo odmienne. Najogólniej mówiąc, dla pierwszego struktury są wtórne wobec ludzkich działań, które tworzą historię, podczas gdy dla drugiego wszelkie działania i sama historia podlegaja, poniżej i powyżej poziomu możliwych swobodnych wariantów, ogólnym i obiektywnym prawidłowościom strukturalnym.

Sartre nie uznaje istnienia struktur rozumianych jako struktury „,samego bytu”, jako konieczne, niezależne od praxis systemowe zależności miedzy jakimiś elementami fizycznymi, a wtórnie lub komplementarnie symbolicznymi. I nie uznaje ich z dokładnie tych samych powodów, z jakich kwestionuje Engelsowską dialektykę przyrody, uznając ją za dogmatyczna. Wbrew tezie Engelsa „doświadczenie krytyczne” nie dostarcza żadnych dowodów na to, że przyroda sama w sobie, czyli niezależnie od naszych z nią relacji i naszych doświadczeń, rządzi się zasadami negacji, sprzeczności czy jedności przeciwieństw. Ale wbrew tezie strukturalistów nie dostarcza też żadnych dowodów na istnienie jakichś niezależnych od doświadczenia ram i zależności, immanentnych dla całej przyrody czy choćby dla ludzkich mózgów, w konieczny sposób warunkujących lub zgoła determinujących działanie i myślenie. Być może takie struktury istnieja, podobnie jak być może istnieje dialektyka przyrody, ale i to jest dla Sartre’a argument podstawowy - to tylko hipotezy rozumu usiłującego wyrwać się ze swojego uwikłania w doświadczenie i zająć „punkt widzenia Boga”. Istnienia struktur, owszem, doświadczamy jako ograniczenia naszych projektów; możemy je nawet rozpoznać jako punkt wyjścia dla każdego projektu, na przykład dostrzegając klasowe struktury społeczeństwa wpływające na sposoby działania i myślenia jednostek. Ale doświadczamy również, na poziomie jednostkowym i zbiorowym, ruchu, który te struktury kwestionuje, nawet jeśli często bezsilnie. Dlatego struktury mieszczą się dla Sartre’a nie po stronie „rzeczy samych", lecz po stronie urzeczowionych praktyk, zakrzepłych w pewnym kształcie

\footnotetext{
9 Rozdziały Struktura i dialektyka oraz Pojęcie struktury w etnologii.
} 
historycznego świata, w pewnym kształcie relacji społecznych, instytucji, jednostkowych i zbiorowych nawyków oraz towarzyszących im poglądów. Sferę tę określa Sartre znaczącym mianem rzeczywistości praktyczno-bezwładnej (le pratico-inerte), w samym tym terminie podkreślając jej mieszany, subiektywno-obiektywny charakter. W sumie struktury istnieja tylko jako historyczny produkt praxis, a wtórnie jako przedmiot zewnętrznej, niedialektycznej wiedzy. Historia nie powstaje wprawdzie w ontologicznej próżni, lecz na bazie przedhistorycznej materii, ale zarówno samo istnienie jakichkolwiek obiektywnych relacji, jak i wszystko to, co można o nich wiedzieć, jest już zapośredniczone przez historyczne działanie. Nigdy nie obcujemy z bytem czy materią w sobie, lecz z bytem zawsze już przetworzonym przez ludzkie działanie i związane z nim myślenie (przez, chciałoby się rzec, praktykę praktyczną i teoretyczna). To zaś, co jest produktem praxis, za sprawą nowej praxis i nowej wiedzy może ulec zmianom, zależnie od podejmowanych przez ludzi projektów. I nawet jeśli rzeczywistość zastygła i odłożona w materii oraz w ukształtowanych sposobach myślenia stawia potężny - może na zawsze nieprzezwyciężalny - opór działaniom podejmowanym bic et nunc (ostateczne wnioski płynące z Critique sa pesymistyczne), nie zmienia to faktu, w każdym razie fenomenologiczno-krytycznego ustalenia, że struktury są wytworem historii i ludzkiej aktywności, a nie dająca się rozpoznać „z lotu ptaka” tekstura bytu w sobie. Miejsce struktur w historii, będącej z definicji historią ludzkich działań w materialnym otoczeniu, jest więc dokładnie takie samo jak miejsce rozumu analitycznego w ramach rozumu dialektycznego: stanowia one element historii i działania, ale nie ich zewnętrzny warunek możliwości, nieprzekraczalną ramę czy istotę.

Stanowisko Lévi-Straussa jest oczywiście przeciwne. Nie przecząc istnieniu historii i historycznych zmian, nie odmawiając pewnej roli świadomemu działaniu, ludzkiej pomysłowości i kreatywności, dzięki którym możliwa była w szczególności rewolucja neolityczna, a znacznie później rewolucja naukowo-przemysłowa (Lévi-Strauss 2001b)10, będzie on stale zaznaczał, a w jawnej polemice z Sartrem szczególnie, prymat ogólnych strukturalnych uwarunkowań nad działaniem i świadomymi projektami. Chociaż na etapie Antropologii strukturalnej strukturze nadawał sens głównie - jeśli nie wyłącznie metodologiczny, uznając ją za rodzaj heurystycznego modelu (Lévi-Strauss 2000)루, to w Myśli nieoswojonej terminowi temu nadaje już sens wyraźnie ontologiczny: struktury gorzej lub lepiej

\footnotetext{
10 Rozdział XVIII, Rasa i historia.

11 Rozdział Pojęcie struktury w etnologii.
} 
się odkrywa, przede wszystkim jednak one realnie istnieją na poziomie zwanym fizycznym i jako takie determinują wszelkie działania i myślenie. Dlatego samą historię można i należy ujmować w sposób strukturalny jako historię szczegółowych wariacji ogólnych inwariantów. Świadomość historycznych aktorów zaangażowanych w „swoją” historię i przypisujących jej wyjątkowe znaczenie nie stanowi tu żadnego kryterium prawdy, przeciwnie, skłania do etnocentrycznych iluzji.

Nie tylko jako badacz, ale także jako obrońca kultur zwanych prymitywnymi LéviStrauss - na poziomie, który trudno uznać za czysto intelektualny, bo w grę dość wyraźnie wchodzą tu także emocje - ma Sartre’owi szczególnie za złe właśnie to, co uznaje za jego zachodni etnocentryzm czy europocentryzm: jego przekonanie, że historia uniwersalna jest ostatecznie tożsama z dynamiczną, „gorącą" historią Zachodu, z jej konfliktami międzyjednostkowymi i klasowymi, zaborczym stosunkiem do przyrody, rewolucjami, kapitalizmem itd. W gruncie rzeczy taki sam zarzut mógłby postawić Marksowi i całej marksizującej lewicy (tak jak w Opium intelektualistów zrobił to, choć nie w imię strukturalizmu, Aron, zarzucając marksistom „ubóstwienie historii”; Aron 2000). Z perspektywy LéviStraussa Sartre jest jednak szczególnie wygodnym przedmiotem krytyki nie tyle jako marksista, ile jako fenomenolog czy egzystencjalista rozprawiający o znaczeniu historii z subiektywnego punktu widzenia. Z tej perspektywy momentem zwrotnym w historii ludzkości może być „zinterioryzowana” rewolucja francuska. W dziele Sartre’a odwołania do niej pełnią faktycznie bardzo ważną rolę, czyniąc $z$ niej rodzaj wzorca zachowań rewolucyjnych, kiedy zastane struktury społeczne zostaja przynajmniej na pewnym poziomie i na pewien czas zburzone za sprawą ludzkich projektów i działań zbiorowych. Dla LéviStraussa jest to mit porównywalny z mitami społeczeństw pierwotnych, chociaż te ostatnie odwołują się raczej do wiecznego porządku. Właściwie cała koncepcja historii w stylu Sartre’a jest mitem, opowieścią, która wydarzenia należące do historii pewnej części ludzkości wykłada jako historię świata, nieświadoma tego, że obiektywnie rzecz biorąc, każda historia rozpada się na szereg wydarzeń, które dają się porządkować na różnych poziomach i w ramach rozmaitych klas zdarzeń (aż po chemiczno-fizyczne) oraz rozmaitych klas dat (Lévi-Strauss 2001a, 337-339, 342-349). Ich obiektywne znaczenie zawsze wymyka się zarówno bezpośrednim uczestnikom, jak i zaangażowanym interpretatorom lekceważącym bezstronną analizę. 
Mitologizując historię Zachodu, w tym samej Francji, Sartre nie jest w stanie docenić kultur zwanych prymitywnymi, które zdają się nie mieć historii lub których historia jest „zimna”. Z jego perspektywy są to społeczeństwa bezwładne, reprodukujące raz wytworzone struktury, rezygnujące $\mathrm{z}$ ich przekształcania. Lévi-Straussa najwyraźniej boli to, że wspominając o tych społeczeństwach w Critique, Sartre nazwał je, choć incydentalnie, „ludzkością karłowatą i niekształtną” (Sartre 1960, 203)12. Dziewiąty rozdział Myśli nieoswojonej, podobnie jak cały Smutek tropików, jest w dużej mierze żarliwą obroną tej rzekomo niższej, upośledzonej formy ludzkości, próbą wykazania, że jej mity nie są gorsze od mitów kultury zachodniej, a stosowane przez nią techniki poznawcze i praktyki, łącznie z magicznymi, w dużym stopniu - na ogólnym poziomie strukturalnym - odpowiadaja nowoczesnym metodom i praktykom naukowym, zarazem analitycznym i całościującym, służącym poszukiwaniu analogii i powiązań przyczynowo-skutkowych, uznającym całą rzeczywistość, ludzką i nieludzką, za system wymiany informacji (Lévi-Strauss 2001a, 354 356).

Ten aspekt sporu między naszymi bohaterami ma oczywiste znaczenie praktyczne, tj. moralno-polityczne, a nie tylko teoretyczne. Trzeba jednak właściwie je rozpoznać. Bzdurą byłoby uznawanie Sartre’a za choćby mimowolnego rzecznika europocentryzmu rozumianego jako przekonanie o wyższości faktycznej historii i cywilizacji zachodniej nad innymi. Już w czasie wojny w Algierii, czyli w okresie pokrywającym się z pisaniem Critique, Sartre bardzo zdecydowanie opowiadał się za prawem ludów kolonizowanych do odrzucenia europejskiej „kurateli”, uznając nawet ich prawo do przemocy, czemu jaskrawy wyraz dał w swojej przedmowie do książki Frantza Fanona (Fanon 1985). W jego refleksji politycznej bardzo łatwo zauważyć skłonność, dość zreszta typową dla całej ówczesnej lewicy, do traktowania społeczeństw „Trzeciego Świata” jako odpowiednika czy zamiennika proletariatu, słusznie dążącego do zerwania swoich kajdan. Ta myśl polityczna ma solidne zakorzenienie w Sartre’owskiej antropologii, która opiera się ostatecznie na tezie, że człowiek nie ma określonej natury (zgodnie z wcześniejszą terminologia - jest „nicością”), wszelkie charakteryzujące go empirycznie cechy maja zatem wymiar historycznie przygodny i wszystkie kultury są tak samo przygodne. Dominacja kultury zachodniej, poza tym że przygodna, jest skrajnie niesprawiedliwa w tej mierze, w jakiej oznacza empiryczne ograniczenie wolności jednych na rzecz innych, chociaż ontologicznie wszyscy sa wolni tak samo, powinni mieć

12 Cytowane przez Lévi-Straussa (2001a, 330). 
zatem jednakową możliwość określania swojego bycia. Na poziomie ontologicznym ludzkość jest dla Sartre’a jedna właśnie dlatego, że człowiek jest bytem nieokreślonym, „niegotowym” i mogącym nadawać sobie różne szczegółowe określenia. Ale z tego samego powodu, na gruncie tejże ontologii, za szczególnie „ludzkie” filozof musi uznawać zrywanie z zastanymi określeniami, próby przekraczania status quo, bunt. Ostatecznie człowiekowi ,jako takiemu" chodzi - powinno chodzić - o wolność i równość z innymi. Dlatego Sartre może entuzjastycznie wspierać ruchy narodowowyzwoleńcze w „Trzecim Świecie”, a jednocześnie nie mieć zrozumienia dla plemion czy kultur podtrzymujących „odwiecznie” pewne sposoby życia, z ich rytuałami, klasyfikacjami i hierarchiami. Chciałby wciągnąć te plemiona/kultury do „gorącej” historii - nie po to, aby stały się podobne do „nas Europejczyków”, ale by na nowo szukały siebie, dążąc do większej równości i lepszej realizacji wolności. Jeżeli uznamy, że idea wolności, równości i braterstwa jest charakterystyczna wyłącznie dla kultury zachodniej, i to w jej późnej, nowożytnej fazie, to oczywiście wypada zgodzić się z LéviStraussem, że myśl Sartre’a na głębokim poziomie pozostaje europocentryczna. Ale dopiero na tym poziomie.

Najogólniejszym pytaniem padającym w Critique jest pytanie o możliwą jedność historii. Sartre bynajmniej nie zakłada, że w „punkcie wyjścia” albo już dziś historia jest faktycznie jedna. Jej jedność jest raczej zadaniem. W punkcie wyjścia istnieje wiele jednostkowych i grupowych praktyk powiązanych skomplikowanymi więziami, które powinien rozjaśnić rozum dialektyczny, ale częściowo niezależnych od siebie i podlegających tylko prawu „serialności” (które najbliżej chyba odpowiada prawu strukturalnemu w ujęciu Lévi-Straussa). Jedność historii (a zarazem jej sens, do czego jeszcze przejdziemy) w tym rozumieniu może stać się faktem tylko dzięki powszechnej walce o wolność i równość - tylko zatem dzięki intencjonalnej praxis - nawet gdyby ta miała się nie powieść. Najkrócej mówiąc, jest tylko i aż jednością możliwie powszechnego celu.

Dla Lévi-Straussa jest to oczywiście metafizyka w złym sensie tego słowa. Chociaż w polemice z Sartrem nigdzie nie mówi tego wprost, wydaje się jasne, że oświecenioworewolucyjne hasła są dla niego właśnie hasłami, składnikami pewnego mitu. Ze strukturalistycznej perspektywy podejrzane jest zwłaszcza hasło „wolność”, którego realną treść wypada sprowadzić do możliwości tworzenia lokalnych wariantów ogólniejszych struktur. Równość także jest problematyczna, przynajmniej jeśli rozumieć przez nią zasadnicze podobieństwo ludzkich celów i praktyk kulturowych, bo na pierwszy rzut oka 
widać, że ludziom Zachodu i członkom kultur „prymitywnych” chodzi o coś innego. Na tym poziomie ani ludzkość, ani tym bardziej historia nie stanowią i - co więcej - nie powinny stanowić jedności, bo mogłoby to oznaczać tylko przemocowe ujednolicenie, podporządkowanie innych „nam Europejczykom”. W tekście Rasa i historia, napisanym na zamówieni ONZ, autor wywodzi również, że hipotetyczne ujednolicenie kultur równałoby się zanikowi kultury w ogóle, ta bowiem może istnieć tylko jako system różnic (Lévi-Strauss 2001b). Ostatecznym uzasadnieniem takiej tezy pozostaje dla Lévi-Straussa językoznawstwo strukturalne, a ściślej sama teoria de Saussure’a, zgodnie z która język istnieje tylko jako system różnic występujących na rozmaitych poziomach, od fonologicznego poczynając. Całościowa struktura, „żyje” tylko poprzez różnicowanie swoich elementów. To samo przekonanie pozwala Lévi-Straussowi twierdzić, że pomimo różnic, a raczej dzięki nim, ściślej zaś dzięki sieciom relacji między nimi, istnieje struktura jako ogólny system, a w jego ramach wiele podsystemów-podstruktur, zarazem różnych od ogólnego systemu i pozostających z nim w stosunkach analogii, jeśli nie izomorfii. W ten sposób Lévi-Strauss przywraca ideę jednej ludzkości, a nawet jednej historii. A także ideę ogólnoludzkiej równości. Podstawą jedności i równości nie są już ludzkie cele, ani tym bardziej świadome przeżycia, lecz w znakomitej mierze nieuświadomione strukturalne uwarunkowania i zależności. Nie jest nią również Sartre’owski brak natury, ludzka nieokreśloność i „nicość”, lecz przeciwnie ostatecznie taka sama natura wszystkich ludzi i wszystkich kultur, niezależnie od różnic istniejących między nimi, związana ze strukturami ludzkiego umysłu w ogóle, a w końcu samej przyrody. Która to przyroda, jak należy wnioskować, jest również systemem różnic analogicznym do systemu języka i nie mniej niż on rygorystycznym, chociaż dopuszczającym liczne wariacje i w tym sensie - wolność.

W sumie zarówno Sartre, jak Lévi-Strauss wierzyli, choć każdy na swój sposób i na gruncie własnych założeń, w jedność ludzkości i fundamentalną równość wszystkich ludzi. Obaj byli bez wątpienia myślicielami „postępowymi”. Obaj sytuowali się na politycznej lewicy. Różnica między ich stanowiskami z pewnością nie jest absolutna nie tylko dlatego, że, jak starałam się pokazać, każde z nich zawiera w sobie element swojego „przeciwieństwa”, ale i dlatego, że ostatecznie obydwa stanowiska wpisują się z powodzeniem w uniwersalistyczną tradycję oświecenia. Spór między nimi ilustruje raczej wewnętrzne napięcia tej tradycji, rozciagniętej między biegunami „subiektywistycznym” i „obiektywistycznym”. A także „praktycznym” i „teoretycznym”. Albo chcemy zmieniać 
świat, stawiając na subiektywnie przeżywane projekty, albo chcemy go w założeniu bezstronnie poznawać, znajdując w nim głównie granice dla możliwego działania. I chociaż alternatywa zarysowana w tak wyostrzony sposób jest niewątpliwie fałszywa, nie da się jej całkowicie zatrzeć ani unieważnić.

Zasadnicza różnica między myśleniem Sartre’a i Lévi-Straussa, choć w ich jawnej polemice nigdy nieujawniona wprost, polega wreszcie na sposobie, w jaki rozumieli „sens” sam termin, ale także genezę zjawisk, które można uznać za sensowne czy znaczące. Nie jest to wprawdzie różnica specyficzna dla nich, w grę wchodzi bowiem ogólna odmienność perspektywy egzystencjalno-fenomenologicznej i obiektywistyczno-strukturalistycznej, ale na przykładzie ich stanowisk widać bardzo dobrze, na czym ta odmienność polega. Dla Sartre’a źródłem sensu może być tylko działający i świadomy podmiot, jednostkowy lub zbiorowy. Sens to tyle co subiektywne przeżywanie relacji ze światem w kontekście pewnego projektu. Z tej perspektywy bezzasadne jest mówienie o sensie bez odwołania do przeżyć i projektów. A skoro projekty to i cele: sens ma naturę teleologiczną, wiąże się z dążeniami i obejmuje antycypowaną oraz pożądaną przyszłość. Sam w sobie byt nie ma sensu, nadają mu go tylko ludzkie dążenia. I tylko z tej perspektywy można pytać o sens historii, która „sama w sobie” sensu nie ma, bo donikąd sama przez się nie zmierza, ale może go uzyskać dzięki ludzkim projektom. Sartre zakłada, sądząc, iż zgadza się tu z Marksem, że sens historii może nadać powszechne dążenie do „królestwa wolności”, do stanu, w którym ludzie byliby „naprawdę wolni, równi i zbratani” (Sartre 1972). Inna sprawa, że w świetle jego własnych rozważań z Critique, zwłaszcza drugiego, niedokończonego tomu, osiagnięcie tego celu wydaje się na zawsze niemożliwe ${ }^{13}$. Ale nawet jeśli projekt wolnościowo-równościowy stanowi tylko focus imaginarius, to również tylko on nadaje treść wyrażeniu „sens historii”.

Dla Lévi-Straussa takie rozumienie sensu historii jest oczywiście mitem. Ale źródło jego niezgody ze stanowiskiem Sartre’a leży głębiej i dotyczy samej genezy „sensu”. Nie odrzucając całkowicie roli, jaką spełniaja subiektywne przeżycia i dążenia, promotor strukturalizmu uważa je za podrzędne w stosunku do gry między nieuświadomionymi elementami systemu. Z tej perspektywy to właśnie owa gra, którą można interpretować jako uniwersalną wymianę informacji w przyrodzie, rodzi także systemy symboliczne i związane z nimi „sensy”, częściowo postrzegane na poziomie świadomości przez same zaangażowane

13 O tym, że Sartre’owska próba syntezy marksizmu i egzystencjalizmu prowadzi do pesymistycznych wniosków co do szans „usensownienia historii”, pisałam w swojej książce (Kowalska 1997, rozdział W stronę historii). 
jednostki, ale w znakomitym stopniu dostępne dopiero oczom niezaangażowanego obserwatora-badacza odkrywającego mechanizm, dzięki któremu „sens” powstaje. I tak o sensie mitu, którego treść podlega różnym wariacjom, zmianom w czasie i przestrzeni, nie decyduja przeżycia tych, którzy ten mit przekazuja i w niego wierza, lecz formalne relacje między jego podstawowymi elementami. Sens przeżywany jest sensem wtórnym, podrzędnym. A nawet mistyfikującym, bo przesłaniającym konieczności, za sprawa których mit uzyskuje taką, a nie inną strukturę.

Ostatecznie wracamy stale do tego samego: mimo nomen omen dialektyki wiążącej stanowiska Sartre’a i Lévi-Straussa istnieje między nimi nieredukowalna różnica, polegająca na przyznawaniu większego znaczenia odpowiednio „podmiotowi” lub „przedmiotowi”, świadomemu doświadczeniu lub jego nieuświadomionym warunkom, a także, last not least, zaangażowanej praktyce lub (pozornie niezaangażowanej) teorii.

\section{W miejsce podsumowania: współczesne konteksty historycznego sporu}

Filozofia po Sartrze i Lévi-Straussie tylko pozornie wyszła poza dzielący ich spór, nawet jeżeli przesunęła go na inny poziom, odrzucając zarówno pojęcie przejrzystej świadomości (które na dobrą sprawę odrzucał już późny Sartre), jak i ideę uniwersalnych struktur ograniczających historyczną zmienność i kreację. Problem podmiotu i praktyki oraz ich relacji z tak czy inaczej rozumianym systemem warunków (nawet gdy nazwie się go różnią) pozostaje najpierw implicite obecny, a wkrótce wprost nazwany przez tzw. myślicieli poststrukturalistycznych, bardzo niechętnych Heglowi i dystansujących się od perspektywy fenomenologicznej. Najlepiej widać to na przykładzie Foucaulta, nie tylko ściśle wiążącego wiedzę z władzą, zatem z praktyką, ale też stopniowo rehabilitującego pojęcie podmiotu, a nawet prawdy powstającej dzięki niemu, dzięki jego „trosce o prawdę” i „praktykom prawdy”. Pojęcie podmiotu będzie istotne także dla Deleuze’a, chociaż zrobi on wiele, aby oddzielić je od świadomego „ja”, a związać z nieświadomym, bezosobowym polem intensywności, z „pojedynczościami” czy „osobliwościami” poniżej progu osobowego, które w tym polu moga się krystalizować i je przekształcać. W każdym razie podmiot pozostaje ośrodkiem aktywnej zmiany warunków powołujących go do życia, jest twórczy i to za jego sprawą z chaosu różnic może powstać „efekt sensu”. Dlatego koncepcje Foucaulta 
i Deleuze’a można bez nadużycia interpretować jako filozofie aktywistyczne i wolnościowe, w czym osobliwie zbliżają się do filozofii Sartre’a. Na swój sposób zbliża się do niej również późny Derrida, medytujący nad problemami sprawiedliwości, demokracji czy przyjaźni i widzący w nich rodzaj zawieszonej nad historią obietnicy. Podmiot i „człowiek” bynajmniej zatem nie gina, choć ich pojmowanie coraz bardziej się komplikuje, choć ich status w relacji do tego, co niepodmiotowe i nieludzkie, jest coraz bardziej niepewny i niejasny. Ale w łonie tej komplikacji wciąż obecne jest napięcie między momentem subiektywnym i praktycznym a przedmiotowo-teoretycznym, ,wewnętrznym” i ,zewnętrznym”.

Dzisiaj jednak to już nie poststrukturalizm stanowi aktualny kontekst, w którym spór Sartre’a z Lévi-Strausem może odzyskać znaczenie. Propozycje Foucaulta, Deleuze’a czy Derridy, choć wciąż inspirujące, same stają się klasyką i jako takie przechodzą do historii. Tym, co przydaje omawianemu sporowi świeżości, jest całkowicie współczesna sytuacja myślenia, a także, jeśli nie przede wszystkim, współczesna sytuacja polityczna. Tytułem podsumowania, a raczej zamiast podsumowania wskażę w wielkim skrócie elementy tej sytuacji.

W porządku intelektualnym wyjątkową ostrość osiąga dziś spór o stosunek filozofii do nauk pozytywnych (w języku bohaterów tego artykułu: rozumu dialektycznego do analitycznego). Wobec triumfalnego pochodu nauk i, co ważniejsze, wyraźnego zwycięstwa „ducha pozytywizmu” w społecznym myśleniu o świecie, filozofia - dziś w znacznie większym stopniu niż w czasach Sartre’a - znalazła się w pozycji defensywnej. O ile nie chce być samą tylko historią filozofii (którą na upartego można podciągnąć pod humanistyczne nauki pozytywne) albo samą tylko metodologia nauki, musi bronić swojego prawa do „myślenia inaczej” i to prawo uzasadniać. „Inaczej” nie znaczy „wbrew nauce”, ale w inny sposób albo na innym poziomie. Pytanie brzmi, czy ten inny sposób lub poziom można uzasadnić inaczej, niż odwołując się do subiektywnych, jednostkowych i zbiorowych doświadczeń, do subiektywnego i przynajmniej potencjalnie intersubiektywnego sensu. A zatem do wartości, idei, projektów, działania itp. - czyli całego „humanistycznego lamusa”.

Wciąż w porządku intelektualnym, ale już na poziomie konkretnych problemów rozważanych dziś zarówno w nauce, jak i w filozofii oraz na granicy przebiegającej między nimi (przede wszystkim w ramach tzw. kognitywistyki) spór Sartre’a i Lévi-Straussa przynajmniej sprowadzony do swojego „jądra” - odzyskuje aktualność w kontekście dyskusji dotyczących statusu umysłu, a zwłaszcza świadomości. Chociaż w dzisiejszych cognitive sciences 
dominują naturaliści, a nawet fizykalistyczni redukcjoniści, dyskusja jest wciąż otwarta. Nie dzieli już ona na ogół „kartezjanistów” i „spinozystów” - tych, którzy uznają odrębność substancji myślącej od fizycznej, i tych, którzy uznają tylko jedną substancję bo „rozdzielczość” analizy problemu i sam język dyskusji znacznie się zmieniły i rozwinęły nie tylko w porównaniu z siedemnastym wiekiem, ale i w porównaniu z językiem Sartre’a czy Lévi-Straussa. Odmienność perspektyw, w jakich ujmowany jest ten problem, pozostaje jednak uderzająca mimo prób szukania „trzeciej drogi”, na przykład w ramach tzw. heterofenomenologii, między podejściem „pierwszoosobowym” i „trzecioosobowym”, fenomenologiczno-subiektywistycznym i naturalistyczno-obiektywistycznym. W tym kontekście warty rozważenia jest fakt, że zarówno Sartre, jak Lévi-Sartre na swój sposób także szukali „trzeciej drogi”, wyjścia poza opozycję idealizmu i fizykalizmu, w praktyce zbliżając się jednak do jednego lub drugiego z tych biegunów. Z czego można wyciagać wniosek, że sprzeczności między „subiektywizmem” i „obiektywizmem” ostatecznie usunąć się nie da.

W porządku tyleż teoretycznym, co praktycznym ważnym współczesnym kontekstem dla sporu Sartre/Lévi-Strauss jest problem ekologii i ściśle z nim związane pytanie o faktyczny oraz pożądany stosunek między naturą i kulturą. Nie ulega wątpliwości, że chyba ostatnim myślicielem, którego wzięliby na swoje sztandary ekologowie, jest Sartre, beznadziejnie antropocentryczny, aktywistyczny i mimo całego swojego materializmu antynaturalistyczny, przyrodę postrzegający przede wszystkim jako opór w dążeniu do wolności. Znacznie bardziej ekologiczne jest myślenie Lévi-Straussa, zgodnie z którym kultura, choć różna od natury, podlega ostatecznie tym samym uniwersalnym prawom, co najlepiej widać w przypadku społeczeństw „prymitywnych”, zachowujących ścisła więź z przyrodą. Lévi-Strauss otwiera też szeroko wrota współczesnemu posthumanizmowi, przekonaniu, że człowiek nie stanowi bynajmniej wyróżnionego ośrodka w bycie, lecz wraz ze zwierzętami, rzeczami i własnymi produktami, kulturowymi i technicznymi artefaktami, jest elementem ogólnego kosmicznego systemu. Z drugiej wszelako strony, to myśl Sartre’a dostarcza argumentów na rzecz tezy, również bardzo aktualnej, że po kolejnych rewolucjach technologicznych znaleźliśmy się w epoce „antropocenu”, stanowiącej novum jeśli nie w historii wszechświata, to przynajmniej Ziemi, której pierwotny system ekologiczny został radykalnie przekształcony, gdzie natura stała się kultura, a już na pewno od kultury czy raczej cywilizacji - zależy. Taki punkt widzenia nie eliminuje troski ekologicznej. 
Ale z postulatu zachowania ekosystemu, a także „humanitarnego” stosunku do zwierząt czyni - podobnie jak z postulatów wolności i równości - ludzką sprawę, pożądany cel naszych projektów. Spór między humanistyczną perspektywą Sartre’a i posthumanistyczną perspektywą Lévi-Straussa nie został zatem zażegnany i odradza się w samym sercu myślenia ekologicznego.

Większe niż tylko teoretyczne znaczenie ma dziś problem możliwej jedności historii i związane z nim pytanie o jedność ludzkości. Praktycznego, a wręcz praktycznie naglącego charakteru nadaje tym pytaniom postępująca globalizacja na poziomie technologicznym i ekonomicznym, której drugą stroną są narastające konflikty przybierające postać konfliktów kulturowych, w szczególności między „światem zachodnim” i „światem islamu”. W tym kontekście szczególną aktualność uzyskuje pytanie o charakter i zakres kultury zachodniej oraz jej relacje z innymi kulturami, o znaczenie uniwersalizmu i jego podstawy, o status i rolę kulturowych różnic. Jak widzieliśmy, Sartre i Lévi-Strauss, chociaż obydwaj byli uniwersalistami, na te pytania odpowiadali zupełnie inaczej i z ich odpowiedzi płyną odmienne praktyczne wnioski. Nieco upraszczając, Sartre byłby - pewnie również dziś zwolennikiem integracji rozumianej jako włączanie wszystkich kultur do ogólnoludzkiego projektu równościwo-wolnościowego, podczas gdy Lévi-Strauss zalecałby zachowanie ich „,naturalnej” odrębności, a na ile to możliwe - także ich przestrzenne rozdzielenie. Sartre postulowałby działania na rzecz oświeceniowej emancypacji muzułmanów w ramach globalnego społeczeństwa, Lévi-Strauss opowiadałaby się pewnie za zostawieniem ich w spokoju. I chociaż dość dobrze już dzisiaj wiemy, że każda z tych opcji jest abstrakcyjna, nierealistyczna i obosieczna, a potencjalnie nawet katastrofalna w skutkach, że w praktyce trzeba szukać rozwiązań gdzieś pośrodku, to wybór między uniwersalizmem w stylu Sartre’a lub Lévi-Straussa stanowi bardzo aktualny dylemat moralny i polityczny.

Na koniec - spór między Sartrem i Lévi-Straussem zachowuje lub odzyskuje świeżość w kontekście współczesnych dyskusji o sensie „lewicowości”, lewicowego myślenia i lewicowej polityki. Czy i na ile lewicowi intelektualiści, a przynajmniej pośrednio także politycy musza jeszcze wierzyć w „człowieka” i jego umiejętności sensotwórcze, w jego istotową wolność i dążenie do wolności empirycznej? W postęp i w uniwersalne projekty emancypacyjne? Jak powinniśmy rozumieć równość i jakie znaczenie przypisywać kulturowym różnicom? Czy i na ile opowiadać się po stronie racjonalności reprezentowanej przez współczesne nauki (,rozum analityczny”)? Czy wiązać nadzieje z ich rolą 
emancypacyjną, czy też w rozwoju cywilizacji naukowo-technicznej widzieć raczej zagrożenie? Czy i w jakim stopniu lub w jaki sposób wychodzić poza antropocentryzm i humanizm? To tylko niektóre, najbardziej ogólne pytania, na tle których myśl „postępowa” wydaje się dziś równie niejednoznaczna, a nawet wewnętrznie skłócona jak na początku lat sześćdziesiątych dwudziestego wieku.

Nie twierdzę, że do tekstów Sartre’a i Lévi-Straussa trzeba dziś wracać, aby szukać w nich odpowiedzi na współczesne pytania, chociaż ponowna lektura klasyków bywa inspirująca. Twierdzę tylko, że w ich tekstach $\mathrm{i}$ w dyskusji między nimi te pytania są już zawarte, a dzielący ich spór w żadnym razie nie został rozstrzygnięty ani w porządku teoretycznym, ani w porządku praktycznym. 


\section{Wykaz literatury}

Althusser, Louis. 1972. „O stosunku Marksa do Hegla”. Tłum. Marek J. Siemek. Cqłowiek i swiatopoglad 6/83.

Althusser, Louis. 2009. W imie Marksa. Tłum. Michał Herer. Warszawa: Krytyka Polityczna. Aron, Raymond. 2000. Opium intelektualistów. Tłum. Czesław Miłosz. Warszawa: Muza.

Descombes, Vincent. 1997. To samo i inne. Cžterdzieśsi pię́ lat filozofii francuskiej (1933-1978).

Tłum. Bogdan Banasiak i Krzysztof Matuszewki. Warszawa: Spacja.

Fanon, Frantz. 1985. Wyklety lud ziemi. Tłum. Hanna Tygielska. Warszawa: PIW.

Kowalska, Małgorzata. 1997. W poszukiwaniu straconej synteঞy. Jean-Paul Sartre i paradygmaty filozoficznego myślenia. Warszawa: Spacja.

Lévi-Strauss, Claude. 2000. Antropologia strukturalna. Tłum. Krzysztof Pomian. Warszawa: Aletheia.

Lévi-Strauss, Claude. 2001a. Myśl nieoswojona. Tłum. Andrzej Zajączkowski. Warszawa:

Wydawnictwo KR.

Lévi-Strauss, Claude. 2001b. Antropologia strukturalna II. Tłum. Maciej Falski. Warszawa:

Wydawnictwo KR.

Pingaud, Bernard i Jean-Paul Sartre. 1966. «Sartre aujourd'hui.» L'Arc 30.

Sartre, Jean-Paul. 1960. Critique de la raison dialectique. T. 1. Paris: Gallimard.

Sartre, Jean-Paul. 1972. Plaidoyer pour les intellectuels. Paris: Gallimard. 
Małgorzata Kowalska - profesor filozofii, kierownik Katedry Filozofii i Etyki na Wydziale Historyczno-Socjologicznym Uniwersytetu w Białymstoku, interpretatorka współczesnej filozofii francuskiej i tłumaczka wielu tekstów filozoficznych z tego obszaru językowego, poza i ponad specjalnością francuską zajmująca się współczesną filozofią społeczna, polityczną i moralna. Autorka m.in. książek $W$ poszukiwaniu straconej syntezy. Jean-Paul $i$ paradygmaty filozoficznego myślenia, Dialektyka poza dialektyka. Od Bataille'a do Derridy, Demokracja w kole kerytyki.

\title{
DANE ADRESOWE:
}

Wydział Historyczno-Socjologiczny

Uniwersytet w Białymstoku

Plac Uniwersytecki 1

15-420 Białystok

EMAIL: malkowal@gmail.com

CYTOWANIE: Kowalska, Małgorzata. 2016. Struktury, historia i praxis. O sporze Sartre'a z Lévi-Straussem z dzisiejszej perspektywy. Praktyka Teoretycz̨na 4 (22): 105-131.

DOI: $10.14746 /$ prt.2016.4.6

\section{AUTHOR: Małgorzata Kowalska}

TITLE: Structures, history, and praxis. On Sartre's argument with Lévi-Strauss from a today's perspective.

\begin{abstract}
The article recalls the historical debate between Sartre and Lévi-Strauss about the meaning of dialectics (or the relationships between dialectical and analytical reason) which concerned also the concepts of history, structure, subjectivity and consciousness, free practice, all in all - the concept of human and the way of understanding anthropology, more "philosophical" or more "scientific". Instead of simply opposing Sartre's and Lévi-Strauss' views the author tries to show quite complex, "dialectical" play between them, although she stresses also their final contrast connected with the inalienable poles of the whole modern philosophy and culture, more specially those of subjectivism and objectivism, and the constant tension between them. Such a tension is reflected not only in different manners of conceiving of man as such (as being mainly a subject and project or, on the contrary, an object and element of a broader universe), but also in the way of understanding the relationship between culture and nature, and, finally, between different cultures.
\end{abstract}


The purpose of the article is not only to reconstruct a historical issue but also to refer the historical debate to contemporary discussions, both theoretical and practical, moral and political, concerning such questions as the status of mind and consciousness, ecology or possible and desirable relations between West and other cultures. In the author's view in all those quite contemporary debates the tension between rather Sartrian or rather LéviStraussian position remain present and vivid.

KEYWORDS: Dialectics, Anthropology, Phenomenology, History, Subject, Praxis, Structure, Structuralism, Freedom 